\title{
Nearshore patterns of coral reef fish larval supply to Barbados, West Indies
}

\author{
Su Sponaugle*, Robert K. Cowen \\ Marine Sciences Research Center, State University of New York, Stony Brook, New York 11794-5000, USA
}

\begin{abstract}
Although larval supply is essential to the maintenance of many marine populations, relatively little is known about the processes influencing the supply of larvae to nearshore habitats. To measure the temporal and spatial patterns of larval supply to the island of Barbados, West lndies, an array of light traps was deployed at 3 sites along the west coast for 2 spring recruitment seasons (1991-92). Three replicate traps were deployed nightly at a central site, and 3 more traps were situated at both a northern and a southern site on alternate weeks during a 60 d period in 1991. In 1992, 3 replicate light traps were deployed nightly at each of the 3 sites for $70 \mathrm{~d}$. A total of 82 species from 31 families was collected; collections from each year were dominated by species from several families: Atherinidae, Blennidae, Scaridae, Pomacentridae, and Acanthuridae. Temporal patterns of abundance were similar for the majority of the species collected: total larval abundance and diversity was greatest during the second half of the lunar cycle, peaking on the third quarter moon. Spatial patterns of larval supply were also distinct: the overall supply of larvae was typically lowest in the central region of the island. Supply of individual species was usually higher at one or the other or both ends of the west coast compared to the central site, with only 2 exceptions. Varjation in the temporal and spatial pattern of tidal currents may account for patterns in the supply of ichthyoplankton. Temporal patterns of north-south (along shore) tidal flow were similar at all 3 sites: maximum nightly transport to the south occurred during maximum amplitude tides (during the new and full moons), while maximum nightly transport to the north occurred during minimum amplitude tides (during the quarter moons). East-west (onshore-offshore) transport due to tidal flows occurred on a much smaller scale and differed among sites. At the northern and southern sites, nightly transport by tidal currents was generally eastward, or onshore, while at the central site transport was generally west, or of fshore. At both the southern and central sites in 1992, the temporal pattern of larval supply was significantly correlated to east-west transport by tidal currents integrated over the previous night. Onshore transport of larvae by tidal currents may be reduced at the central region of the west coast, resulting in both lower abundances and an overall lower diversity of reef fish larvae there. Patterns in the nightly transport by large-scale, externally forced currents (periods greater than $39 \mathrm{~h}$ ) were generally similar across all sites. Transport by these currents in both the north-south and east-west directions was significantly correlated to the mean number of larvae collected by the light traps, suggesting some influence of external forcing such as wind or other oceanographic features. Thus, larval supply to Barbados appears to be influenced by processes occurring at 2 scales. Behavioral or passive synchronization to the lunar and tidal amplitude cycles results in regular, predictable peaks in the supply of late-stage larvae. Superimposed on this pattern are less predictable, large-scale events which can also greatly influence the nearshore transport of larvae.
\end{abstract}

KEY WORDS: Caribbean coral reef fishes - Larvae - Settlement - Metamorphosis Recruitment - Tides Nearshore currents Oceanography Light traps Lunar periodicity

\section{INTRODUCTION}

The supply of larvae is critical to the maintenance of many marine populations. Open populations, such as those of coral reef fishes, depend upon the return and settlement of planktonic larvae to balance losses due to mortality. Regardless of whether the structure of a pop-

\footnotetext{
•E-mail: ssponaugle@ccmail.sunysb.edu
}

ulation is predominantly dictated by deterministic, postsettlement processes (e.g. reviewed in Jones 1991, Hixon \& Beets 1993), by the recruitment of juveniles into the population (e.g. Doherty 1981, Cowen 1985 , Gaines et al. 1985, Victor 1986, Choat et al 1988, Keough 1988, Roughgarden et al, 1988, Gaines \& Bertness 1992, Peterson \& Summerson 1992, Doherty \& Fowler $1994 \mathrm{a}, \mathrm{b}$ ), or by some combination thereof (e.g. Warner \& Hughes 1988, Forrester 1990, Jones 1990. 
1991, Doherty 1991, Hixon 1991, Hixon \& Beets 1993), the processes controlling larval supply are essential to the replenishment of any population.

As more attention is focused on the dynamics of larval supply, there has been growing interest in the collection of late-stage larvae that are nearing settlement Traditional studies of the supply of coral reef fish larvae typically have used ichthyoplankton surveys to describe the distribution of a variety of larval stages (reviewed in Leis 1991). However, these methods have been limited by an apparent bias against larger, presettlement larvae (e.g. Choat et al. 1993). The current drive to target later larval stages has resulted in several new sampling methods, including purse-seines (e.g. Kingsford \& Choat 1985), moored channel nets (Shenker et al. 1993, Thorrold et al. 1994a, b, c), dipnet night lighting (e.g. Victor 1986, 1991, Smith et al. 1987, Dennis et al. 1991), fixed nets on reef crests (Dufour \& Galzin 1993) and anchored (Doherty 1987, Milicich 1988, 1994, Thorrold \& Milicich 1990, Milicich et al. 1992, Choat et al. 1993, Meekan et al. 1993, Brogân 1994, Milicich \& Doherty 1994) or drifting light traps (Thorrold 1992, 1993).

As with all sampling gear, larval light traps have limitations, the most obvious being the taxonomic bias resulting from the need for active behavior-positive phototaxis and directional swimming-by the larvae. However, several studies have demonstrated that light traps can be useful in addressing fundamental questions of larval supply for selected species (Milicich et al. 1992, Meekan et al. 1993, Sponaugle \& Cowen in press). These studies have shown that the supply of late-stage larvae is closely related to subsequent recruitment of juveniles and that patterns in larval supply (and juvenile recruitment) for some species are controlled largely by rates of larval production (e.g. Meekan et al. 1993). Additionally, for some fish species, patterns of larval supply appear to be temporally coupled to the lunar (Thorrold et al. 1994a, b) and tidal amplitude cycles (Sponaugle unpubl. data). By focusing on only a few species, the isolation of particular aspects of the supply and recruitment process has been possible. An alternative approach is to compare a diversity of species (e.g. for light trap collections; Milicich \& Doherty 1994). This strategy may contribute additional, critical elements to our understanding of the processes influencing larval supply. Similar patterns of larval supply may occur among some species that are in contrast to patterns exhibited by other species. Correlations between these patterns and various physical factors and life history attributes may help explain the processes regulating larval supply.

This study was designed to examine physical and biological factors that may determine temporal and spatial patterns of larval supply to the island of Barbados,
West Indies. Most of the light trap studies to date have been conducted on the Great Barrier Reef, Australia, with recent efforts also targeting the Gulf of California, Mexico (Brogan 1994); there have been no published data on light trap collections of ichthyoplankton from the Caribbean. Therefore, the preliminary goal of this study was to establish which species of Caribbean reef fishes are consistently collected by light traps. Secondly, a spatial array of light traps was deployed during a series of consecutive nights to identify the temporal and spatial patterns of larval supply for the most abundant species. Thirdly, these temporal and spatial patterns of larval supply were related to nearshore current flows and several environmental cycles to determine the potential causes of this variation.

\section{METHODS}

Field sampling. The nearshore region of the west coast of Barbados is characterized by living and dead coral reef outcrops concentrated at small coastal headlands. Isolated spurs of coral matrix extend from the subtidal zone to ca $15 \mathrm{~m}$ depth and are separated by regions of sand and sand-rubble substrates. There are no well-defined backreef-lagoonal regions of seagrass and most settlement by larvae occurs directly onto the nearshore reefs (Sponaugle pers. obs.).

The supply of larvae to the nearshore reefs was monitored by light traps deployed 50 to $100 \mathrm{~m}$ offshore of the nearshore reefs. Larval supply was measured over several months during the spring recruitment season in 1991 and 1992. Spring corresponds to a period of peak larval abundance (Munro et al. 1973, Powles 1975) and high or increasing recruitment for many species of reef fishes (Luckhurst \& Luckhurst 1977. McFarland et al. 1985, Hunt von Herbing \& Hunte 1991, Tupper \& Hunte 1994). In 1991, 3 replicate traps were deployed nightly at a central site along the west coast (off the Bellairs Research Institute) for $60 \mathrm{~d}$. During ca 5 d around each new and full moon, 6 additional traps were deployed: 3 each at a northern site (between the Sandridge Hotel and Six Men's Bay) and at a southern site (between Batt's Rock and Fitt's Village). In 1992, replicate traps were deployed at all 3 sites each night over the entire season (70 d).

Light traps were designed to be functional yet economical. Each trap consisted of a tapered cylinder of nitex $505 \mu \mathrm{m}$ mesh attached at the top to a masonitestyrofoam float and at the bottom to a removable plastic quart jar (Fig. 1). The cylindrical shape of the netting was maintained by a plastic covered heavy-gauge wire ring attached along the trap midline. Three plastic 'funnels' (recycled from 2 I soda bottles) were attached to canvas-reinforced openings spaced equi- 


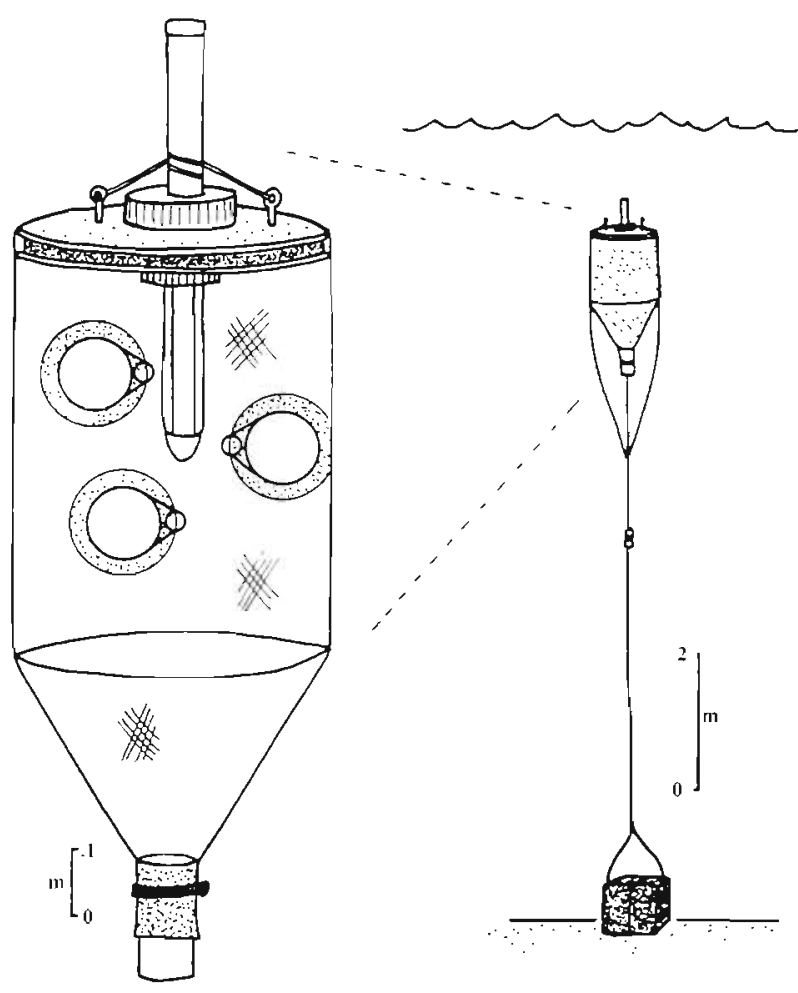

Fig. 1. Schematic diagram of larval light traps. See text for description of materials

distant around the body of the trap. Prior to deployment, a light was inserted through the float and held in place by a neoprene ring (attached to the underside of the float), and nylon cording tied to the top. The light consisted of a $6 \mathrm{~W}$ fluorescent bulb housed in a clear PVC pipe joined to an opaque PVC pipe containing 4 rechargeable high-capacity $\mathrm{NiCd}$ batteries. The 2 halves of the light were joined by a larger diameter PVC pipe connector. Each 'wand' was equipped with a magnetic on/off switch that could be triggered simply by the removal or replacement of a magnet outside of the pipe housing. Three nylon lines were attached to the top of each trap and extended along the trap length, terminating well below the cod end. A brass clip was attached to the end of these lines, enabling quick attachment to and release from the mooring line. Moorings consisted of 3 sets of cement blocks spaced $40 \mathrm{~m}$ apart, parallel to the coast at ca $12 \mathrm{~m}$ depth. Once attached to a mooring, traps were suspended ca $1 \mathrm{~m}$ below the water surface (Fig, 1).

Traps and lights were selected randomly for deployment each evening, and the order that traps were deployed at each site alternated nightly. Deployment entailed attaching each trap to a mooring line and removing the magnet (which switched on the light) by a snorkeller. Traps remained lit for 10 to $12 \mathrm{~h}$. Traps were retrieved the following morning at dawn and the contents of each quart jar were preserved in 5\% formaldehyde for the return boat ride. Traps were washed every morning and allowed to dry in the sun. Batteries were removed from the lights, discharged fully (testing the remaining charge also enabled confirmation of light functioning), and recharged. Samples were sorted daily and larvae were preserved in $70 \%$ ethanol. Larvae were later identified to the lowest taxonomic level possible. There were relatively few problems with the functioning of the light traps; on only 4 nights a single trap failed, and on only 1 night 2 of the 3 traps failed at a site. Collections from these nights were estimated from the remaining trap(s).

In 1992, nearshore currents were measured by 3 current meters (AANDERRA RCM4) that were moored offshore of each light trap site. Meters were moored ca 200 to $300 \mathrm{~m}$ offshore in 23 to $30 \mathrm{~m}$ deep water. The northern and southern meters were located at $4 \mathrm{~m}$ depth and the central meter at $10 \mathrm{~m}$ depth. The magnetic recording tapes from each meter were replaced once in the middle of the season, resulting in 2 separate deployments. Unfortunately, malfunctions resulted in only one usable current meter record from the northern and central sites: the first deployment at central site and the second deployment from the northern site. Hourly wind speeds were obtained from the airport weather station.

Statistical analysis. The mean number of larvae collected in the light traps was tabulated for the most common species. For analysis of the temporal pattern of supply, the number of larvae collected was summed for each night and these values were pooled into a single lunar cycle. Each species was analyzed separately when more than 20 larvae were collected each year. All larvae collected (except for the atherinids) were also summed and similarly analyzed. Atherinids were removed from this analysis because these species school in nearshore surface waters throughout their life history and do not recruit into benthically oriented juvenile and adult populations as do the other reef species. Their presence in the light traps is most likely due to variation in relative light intensity (see 'Results'), Because light traps were deployed every night only at the central site in 1991, only larvae collected from that site were used to analyze temporal pattern for that year. For 1992, collections indicated that patterns in larval supply were generally coincident over all 3 sites (see 'Results'); therefore, the total number of larvae collected each night by all traps could be used for the analysis of temporal pattern. Supply over the lunar cycle was tested using Rayleigh statistics to determine whether supply varied over the lunar cycle (Batschelet 1981, Zar 1984).

Spatial patterns of larval supply were compared for the largest larval supply events from each year. Patterns of abundance of all collected species (except 
atherinids as noted above) were compared among sites for a single event in 1991 and 3 events in 1992. In 1991, only samples from nights when traps were deployed at all 3 sites were used in this analysis. The mean number of larvae and mean number of species collected at each site during an event (e.g. over 15 to 19 d) were compared using non-parametric Kruskal-Wallis procedures (Zar 1984) followed by Tukey-type multiple comparisons (Zar 1984).

The current meter records were analyzed to test whether temporal and spatial patterns of larval supply were related to variations in the flow field. To obtain a general view of the impact of various currents, several filters were applied to the raw physical data to remove noise and separate local hydrographic events from tidal flows. Prior to filtering, each current meter record was divided into east-west (onshore-offshore) and north-south (along shore) components. These records were smoothed with a 65 min boxcar filter, and then decimated to hourly values. The standard Doodson filter was then used to separate currents with periods of less than $39 \mathrm{~h}$ from currents with periods of greater than 39 h (Doodson \& Warburg 1941). The 'low pass filtered' record containing currents with periods greater than $39 \mathrm{~h}$ was representative of large-scale, externally forced current flow, while the 'high frequency' currents with periods less than $39 \mathrm{~h}$ included all tidal and possible inertial currents. Net transport in each direction was calculated for each night of deployment 18:00 to 06:00 h). The moving averages ( 3 point) of each transport record were qualitatively compared among sites. The temporal pattern of larval supply was crosscorrelated to these smoothed current flow records. For simplicity, where records were similar among sites, the mean number of larvae collected across all sites was cross-correlated to the mean of these transport records. Where transport records differed among sites (high frequency east-west record), separate cross-correlations were performed on the physical and biological data from each site.

Prior to the cross-correlations, the biological data were also filtered to remove noise. The raw abundance data were smoothed by fast Fourier transformations (using a 3-point smoothing) with the 'Filtfilt' program in MATLAB (Oppenheim \& Schafer 1975, Krauss et al. 1988). Cross-correlations (lagged up to $30 \mathrm{~d}$ ) were performed with the SYSTAT statistical package (Wilkinson 1987).

\section{RESULTS}

The light traps collected a total of 82 identifiable species or types comprising 31 families (Table 1). There was general. interannual consistency in species rank, with members of 5 families, Atherinidae, Blennidae, Scaridae, Pomacentridae, and Acanthuridae, collected in the greatest abundance each year (Table 1). For the purposes of this study, the atherinids will be treated separately because they remain in nearshore surface waters throughout their life history and do not recruit to the benthos as do typical reef fishes. Although the ichthyofaunal composition was similar between years, the overall abundance of reef fish larvae was variable. Fishing effort was substantially greater in 1992, yet collection of many species was higher in 1991. This was due primarily to a single major pulse in larval supply (corresponding to a large peak in juvenile recruitment; Sponaugle unpubl. data) during 1991 and relatively few large events during the 1992 season (Fig. 2).

\section{Temporal pattern of larval supply}

The abundance of larvae collected in the light traps varied regularly: the greatest numbers and highest diversity of species were collected during the third quarter moon, 7 to $9 \mathrm{~d}$ after the full moon (i.e. Day 22 to 24 of the lunar month; Table 2, Figs. $2 \& 3$ ). This result is not simply due to variation in the relative brightness of the light traps: the contrast between the light emitted by the traps and ambient light would be greatest around the new moon. This is exemplified by the presence of atherinids in the light traps, which were collected during the new moon (Table 2, Fig. 3). Because these fish are always abundant in the nearshore surface waters, variation in their collection is most likely due to relative brightness of the lights. Although periodicity in spawning (e.g. Middaugh et al. 1984) may contribute to pulses in the availability of atherinid larvae, the light traps collected larvae of a range of sizes, as well as juveniles and adults, during each pulse.

Separate analyses of each of the more abundant species indicated that the abundance of most reef fish species peaked during the third quarter moon, with several exceptions (Table 2, Fig. 4). However, not all of these species were collected during every third quarter moon. Among these, several species were always collected together, exhibiting virtually identical temporal patterns of abundance: 2 blennies, Malacoctenus triangularis and Blennidae Type 2, and the bicolor damselfish Stegastes partitus and ocean surgeon Acanthurus bahianus. Four species peaked in abundance between the new and first quarter moon: the reef squirrelfish Holocentrus coruscus, the yellowtail snapper Ocyurus chrysurus, a damselfish Stegastes sp., and the sharpnose puffer Canthigaster rostrata (Table 2, Fig. 4). Only 1 species, the slender filefish Monocanthus tuckeri, demonstrated no significant pattern in its appearance in the light traps. Patterns of lar- 
Table 1. Species collected in light traps deployed off Barbados, West Indies

\begin{tabular}{|c|c|c|c|c|c|}
\hline \multirow{2}{*}{$\begin{array}{l}\text { Family } \\
\text { Species or type }\end{array}$} & \multicolumn{2}{|c|}{ Total abundance } & \multirow{2}{*}{$\begin{array}{l}\text { Family } \\
\quad \text { Species or type }\end{array}$} & \multicolumn{2}{|c|}{ Total abundance } \\
\hline & 1991 & 1992 & & 1991 & 1992 \\
\hline Elopidae & & & Mullidae & & \\
\hline Megalops atlantica? & 18 & 3 & Pseudupeneus maculatus & 0 & 2 \\
\hline Muraenidae & & & Pomacentridae & & \\
\hline Type A & 1 & 0 & Chromis multilineata & 10 & 2 \\
\hline Type B & 1. & 0 & Stegastes partitus & 408 & 60 \\
\hline Engraulidae & & & Stegastes leucostictus & 26 & 65 \\
\hline Anchoa sp. & 15 & 1 & Stegastes dorsopunicans & 24 & 8 \\
\hline Synodontidae & & & Stegastes sp. & 0 & 36 \\
\hline Synodus intermedius & 12 & 21 & Labridae & & \\
\hline Synodus type B & 3 & 1 & Halichoeres bivittatus & 15 & 15 \\
\hline Myctophidae & & & Halichoeres maculipinna & 3 & 15 \\
\hline Type A & 1 & 0 & Xyrichtys sp. & 0 & 1 \\
\hline Carapinae & & & Scaridae & & \\
\hline Carapus bermudensis? & 6 & 16 & Sparisoma viride & 362 & 183 \\
\hline Gobiosocidae & & & Sparisoma sp. & 0 & 1 \\
\hline Type A & 1 & 3 & Sparisoma sp. & 0 & 1 \\
\hline Type B & 1 & 0 & Sparisoma sp. & 0 & 1 \\
\hline Atherinidae & & & Scarus sp. & 14 & 3 \\
\hline Allanetta harringtonensis & 3905 & 2546 & Blennidae & & \\
\hline Holocentridae & & & Malacoctenus triangularis & 672 & 56 \\
\hline Holocentrus coruscus & 0 & 26 & Ophioblennius atlanticus & 137 & 29 \\
\hline Aulostomidae & & & Type 1 & 5 & 2 \\
\hline Aulostomus maculatus & 2 & 2 & Type 2 & 75 & 90 \\
\hline Fistularidae & & & Type 4 & 52 & 16 \\
\hline Fistularia tabacaria & 0 & 1 & Type 5 & 146 & 14 \\
\hline Syngnathidae & & 1 & Type 7 & 26 & 25 \\
\hline $\begin{array}{l}\text { Syngnatmoae } \\
\text { Syngnathus sp. }\end{array}$ & 4 & 2 & Type 10 & 13 & 9 \\
\hline Syngmatnus sp. & 4 & 2 & Type 11 & 6 & 10 \\
\hline Scorpaenidae & & & Type 12 & 20 & 21 \\
\hline Type A & 11 & 2 & Type 13 & 1 & 2 \\
\hline Type B & 6 & 3 & Type 14 & 1 & 0 \\
\hline Type C & 5 & 2 & Type 15 & 9 & 20 \\
\hline Type D & 2 & 0 & Type 16 & 0 & 1 \\
\hline Type E & 3 & 0 & 1ype 10 & & \\
\hline Type F & 0 & 4 & Gobiidae & & \\
\hline Serranidae & & & Gnatholepis thompsoni & 2 & 0 \\
\hline Epinephelus sp. & 0 & 2 & Type B & 1 & 0 \\
\hline Type A & 1 & 0 & Type C & 0 & 1 \\
\hline Type B & 2 & 6 & Type D & 0 & 1 \\
\hline Type C & 3 & 3 & Microdesmidae & & \\
\hline Type E & 0 & 1 & Microdesmus sp. & 3 & 0 \\
\hline Type F & 0 & 1 & Microdesmus longipinnis & 2 & 1 \\
\hline Grammistidae & & & Acanthuridae & & \\
\hline Rypticus sp. & 1 & 0 & Acanthurus bahianus & 82 & 79 \\
\hline Apogonidae & & & Acanthurus coerulus & 0 & 9 \\
\hline Apogon conklini & 0 & 6 & Bothidae & & \\
\hline Apogon maculatus & 0 & 1 & $\begin{array}{l}\text { Botnidae } \\
\text { Bothus ocellatus }\end{array}$ & 8 & 2 \\
\hline Apogon pigmentacius & 0 & 11 & Bothus sp. & 1 & 0 \\
\hline Carangidae & & & Balistidae & & \\
\hline Decapterus punctatus & 0 & 1 & Balistes vetula & 2 & 0 \\
\hline Caranx bartholomaei & $\begin{array}{l}0 \\
0\end{array}$ & $\begin{array}{l}4 \\
1\end{array}$ & Monocanthus tuckeri & 128 & 23 \\
\hline Type B & 0 & $\begin{array}{l}1 \\
1\end{array}$ & Monocanthus ciliatus & 0 & 7 \\
\hline Lutjanidae & & & Ostraciidae & & \\
\hline Lutjanus mahogani & 3 & 0 & Type A & 1 & 0 \\
\hline Ocyurus chrysurus & 7 & 23 & Tetradontidae & & \\
\hline Gerreidae & & & Canthigaster rostrata & 28 & 3 \\
\hline Type A & 3 & 5 & Sphaeroides spengleri & 1 & 0 \\
\hline
\end{tabular}



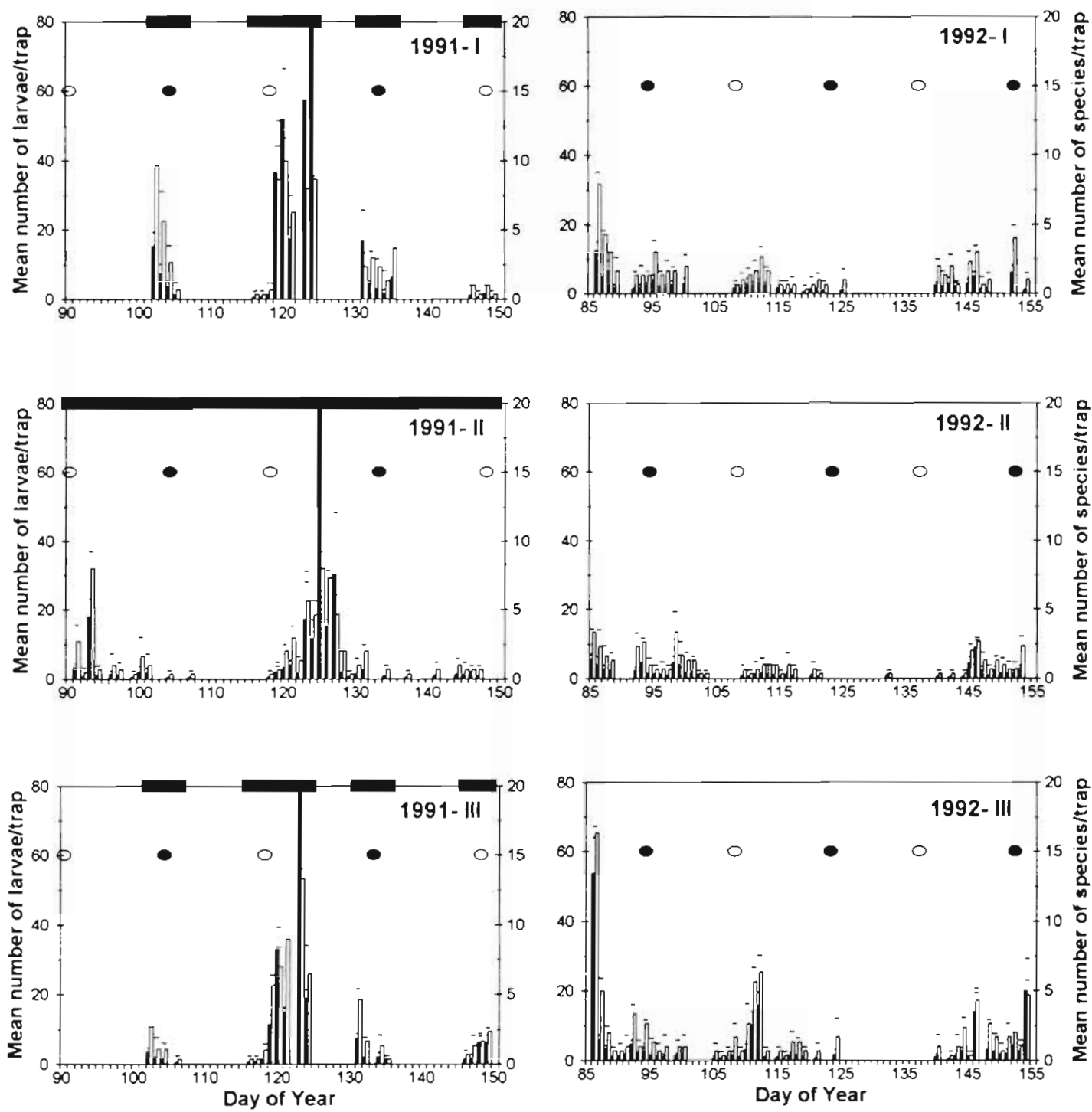

Fig. 2. Mean abundance (solid bars, $+1 \mathrm{SE}$ ) and diversity (open bars, $+1 \mathrm{SE}$ ) of late-stage larvae of all reef fish species collected from 3 replicate light traps at each of 3 sites (I: north; II: central; III: south) along the west coast of Barbados, West Indies. In 1991, traps were deployed nightly throughout the season at the central site and on alternate weeks at the northern and southern sites. The dark bar at the top of each graph indicates sampling nights. Traps were deployed nightly at all 3 sites in 1992

(a) New moon; (O) full moon

val supply were generally consistent between years, except for the redlip blenny Ophioblennius atlanticus (Table 2, Fig. 4). Whereas most $O$. atlanticus larvae were collected during the third quarter moon in 1991, larval abundance in 1992 tended to peak closer to the new moon.

\section{Spatial pattern of larval supply}

For most of the species collected, the temporal pattern of larval supply was spatially concordant over all 3 sites along the west coast of the island (Fig. 2).
Although pulses in larval supply occurred on at least an island-wide scale, site-specific abundance and diversity were variable along the coast. For 3 of the 4 supply events, the abundance of all reef fish larvae collected at the central site tended to be lower than at either of the other sites (Fig. 5). In 1991, this difference was significant between the northern and central sites, and for 2 out of the 3 events in 1992, this difference was significant between the southern and central site (Table 3). For 3 of the 4 supply events, the central site also consistently received a significantly lower diversity of reef fish larvae than the southern site (Fig. 5). In general, the southern site tended to receive both the 
Table 2. Rayleigh statistics to test for lunar periodicity in abundance of larval fishes collected in light traps. Traps were deployed off Barbados during spring 1991 and 1992. 1991 collection from 3 traps deployed at a single site every night for 60 d; 1992 collection from a total of 9 traps deployed at 3 sites every night for $70 \mathrm{~d}$. Rayleigh statistics $(Z)$ computed for species where greater than 20 fishes were collected during a given year. $p<0.01 ; " p<0.001$; ns: $p>0.05$

\begin{tabular}{|c|c|c|c|c|c|}
\hline Species & Year & $n$ & $Z$ & Lunar day & $s$ \\
\hline All species combined ${ }^{b}$ & $\begin{array}{l}1991 \\
1992\end{array}$ & $\begin{array}{r}681 \\
1019\end{array}$ & $\begin{array}{l}527.8 \cdots \\
257.3 \cdots\end{array}$ & $\begin{array}{l}21.7 \\
23.9\end{array}$ & $\begin{array}{l}2.3 \\
4.7\end{array}$ \\
\hline Allanetta harringtonensis & $\begin{array}{l}1991 \\
1992\end{array}$ & $\begin{array}{l}952 \\
486\end{array}$ & $\begin{array}{c}228.2^{\cdots} \\
44.0\end{array}$ & $\begin{array}{r}2.5 \\
28.0\end{array}$ & $\begin{array}{l}4.7 \\
5.6\end{array}$ \\
\hline Synodus intermedius & 1992 & 21 & $5.4^{\circ}$ & 23.6 & 4.7 \\
\hline Holocentrus coruscus & 1992 & 26 & $22.8^{\cdots}$ & 5.0 & 1.7 \\
\hline Ocyurus chrysurus & 1992 & 23 & $7.5^{\circ}$ & 27.1 & 2.9 \\
\hline Stegastes partitus & $\begin{array}{l}1991 \\
1992\end{array}$ & $\begin{array}{l}57 \\
60\end{array}$ & $\begin{array}{l}50.1 \cdots \\
27.5 \cdots\end{array}$ & $\begin{array}{l}21.0 \\
21.1\end{array}$ & $\begin{array}{l}1.7 \\
4.3\end{array}$ \\
\hline Stegastes leucostictus & 1992 & 65 & $41.0^{\circ}$ & 22.9 & 3.0 \\
\hline Stegastes sp. & 1992 & 36 & $32.3^{\cdots}$ & 0.4 & 1.5 \\
\hline Sparisoma viride & $\begin{array}{l}1991 \\
1992\end{array}$ & $\begin{array}{l}284 \\
183\end{array}$ & $\begin{array}{r}243.7^{\circ} \\
61.8^{\circ}\end{array}$ & $\begin{array}{l}22.1 \\
25.1\end{array}$ & $\begin{array}{l}1.8 \\
4.3\end{array}$ \\
\hline Malacoctenus triangularis & $\begin{array}{l}1991 \\
1992\end{array}$ & $\begin{array}{r}139 \\
56\end{array}$ & $\begin{array}{r}123.8^{\circ} \\
27.3^{\circ}\end{array}$ & $\begin{array}{l}21.6 \\
23.6\end{array}$ & $\begin{array}{l}1.6 \\
3.7\end{array}$ \\
\hline Ophioblennius atlanticus & $\begin{array}{l}1991 \\
1992\end{array}$ & $\begin{array}{l}29 \\
29\end{array}$ & $\begin{array}{c}22.4^{\circ} \\
5.7^{\circ}\end{array}$ & $\begin{array}{l}20.2 \\
27.6\end{array}$ & $\begin{array}{l}2.3 \\
5.0\end{array}$ \\
\hline Blennidae type 2 & $\begin{array}{l}1991 \\
1992\end{array}$ & $\begin{array}{l}35 \\
90\end{array}$ & $\begin{array}{l}30.3^{*} \\
38.8^{*}\end{array}$ & $\begin{array}{l}22.4 \\
23.8\end{array}$ & $\begin{array}{l}1.8 \\
3.9\end{array}$ \\
\hline Blennidae type 7 & 1992 & 25 & $13.9^{*}$ & 21.3 & 3.4 \\
\hline Blennidae type 12 & 1992 & 21 & $16.5^{*}$ & 22.0 & 2.2 \\
\hline Acanthurus bahianus & 1992 & 79 & $34.8^{*}$ & 20.0 & 3.9 \\
\hline Monocanthus tuckeri & 1992 & 23 & $2.3^{\text {ns }}$ & - & - \\
\hline Canthigaster rostrata & 1992 & 39 & $4.7^{\circ}$ & 3.3 & 5.4 \\
\hline
\end{tabular}

Day $1=$ new moon

Fig. 3. Variation in larval supply over the lunar cycle. The total abundance of all species and all atherinids collected during 4 complete lunar cycles in 1991 and 1992 was compiled for a single lunar cycle. Day 1 is the new moon. Note that $y$-axis scales differ among species and years
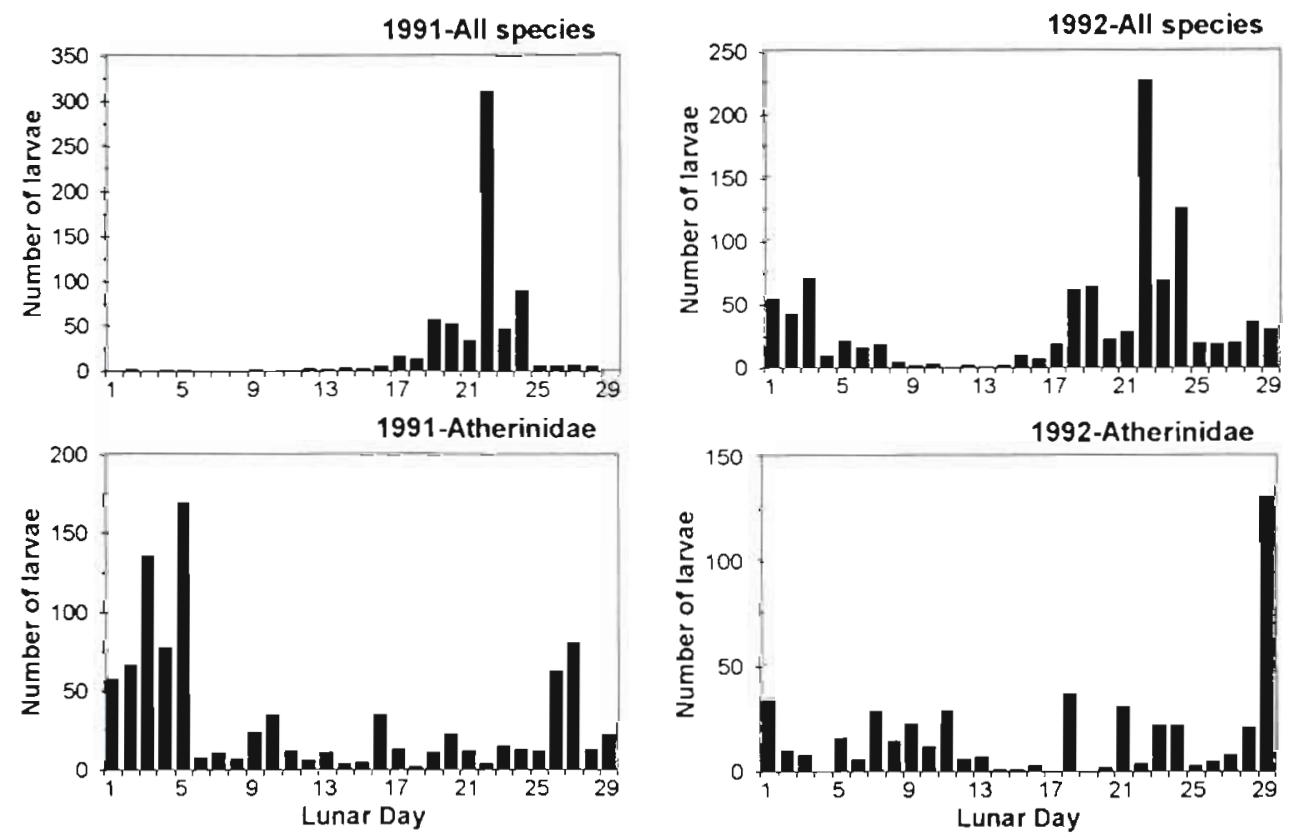

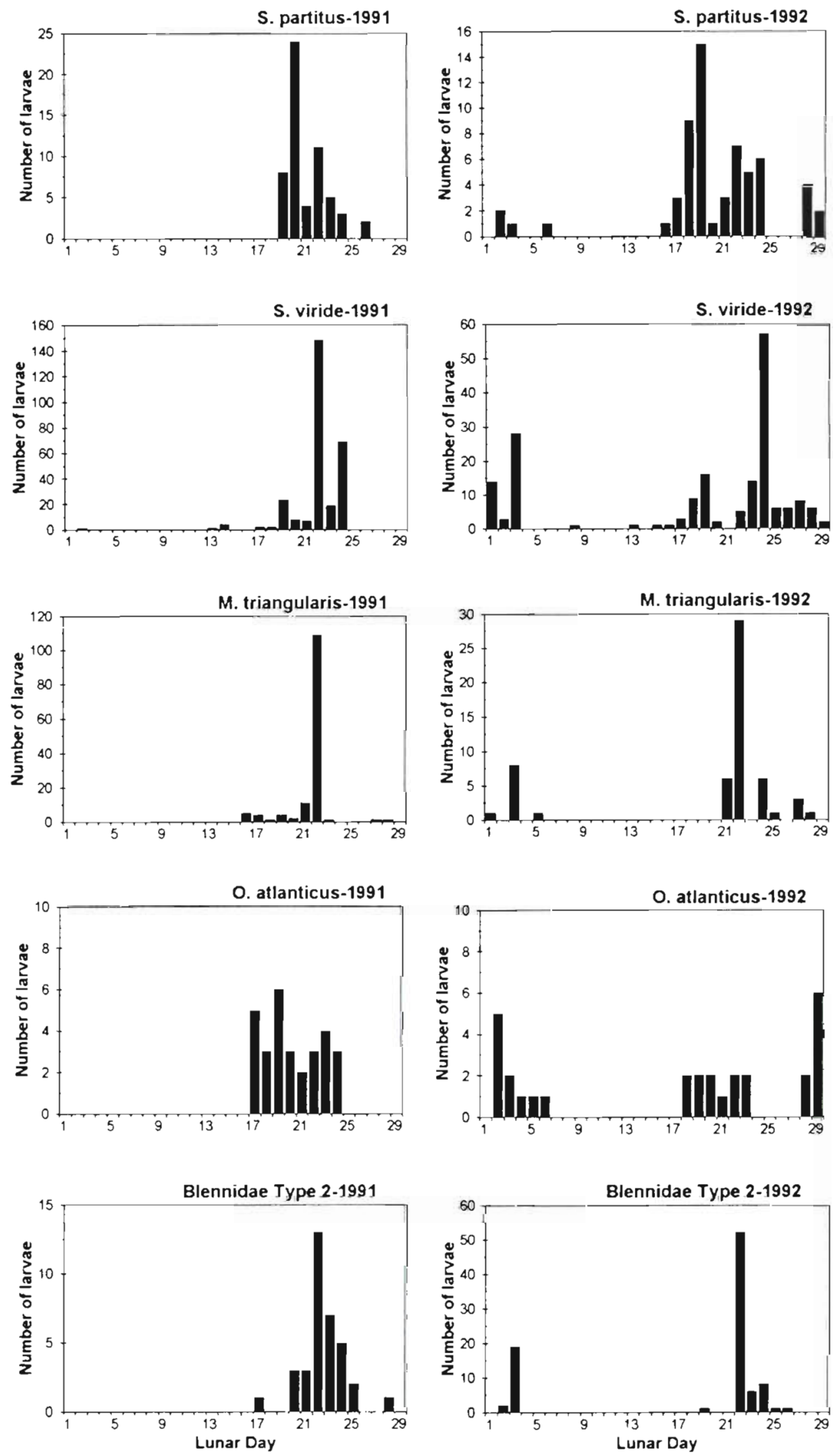

Fig. 4. Distribution of larval supply over the lunar cycle for 15 of the most abundant reef fish species collected in the light traps. For 5 of these species (this page), total abundance was sufficiently high during both years for analysis (see text for criteria). For the remainder of the species (facing page), only the abundance in 1992 is presented. Note that $y$-axis scales difter among species and years 

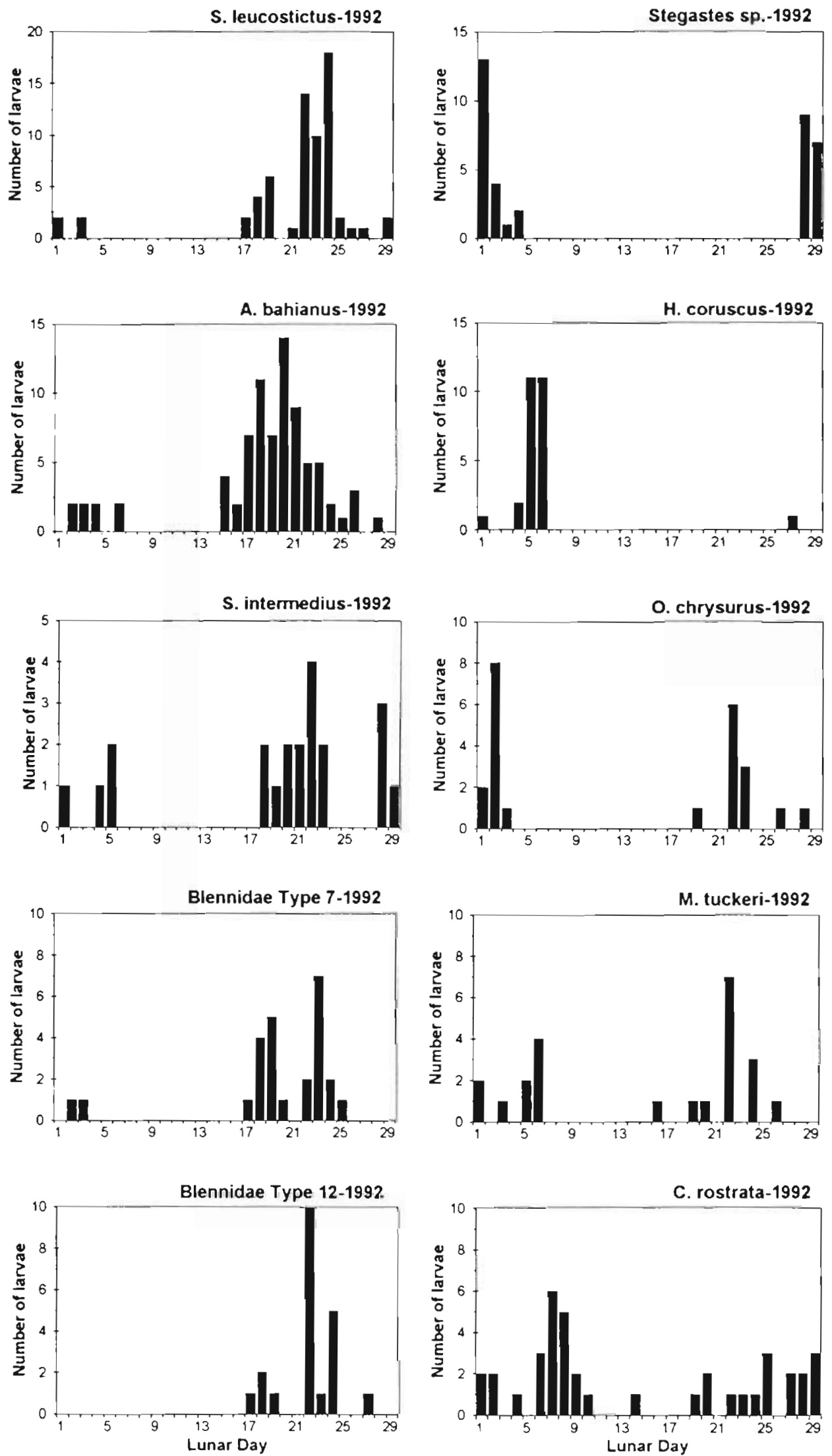

Fig. 4 (continued) 
Table 3. Spatial comparison of larval abundance and diversity in light traps deployed along the west coast of Barbados. KruskalWallis $(H)$ and Tukey-type multiple comparison q statistics are presented for all species (except atherinids; see text) collected during peak recruitment events (a single event in 1991, 3 events in 1992). Larval supply in 1991 was computed only for nights when traps were deployed at all 3 sites. All statistics are significant at $p<0.05$ unless indicated by ns (not significant)

\begin{tabular}{|c|c|c|c|c|c|c|}
\hline \multirow[t]{2}{*}{ Event } & \multicolumn{3}{|c|}{ Abundance } & \multicolumn{3}{|c|}{ Diversity } \\
\hline & $H$ & $q$ & $\begin{array}{l}\text { Among-site } \\
\text { differences }\end{array}$ & $H$ & $q$ & $\begin{array}{l}\text { Among-site } \\
\text { differences }\end{array}$ \\
\hline 1991 & 6.0 & 3.38 & I $>$ II & 7.3 & 3.80 & III > II \\
\hline $1992 a$ & 6.0 & 3.38 & III $>$ II & 6.3 & 3.48 & III $>$ II \\
\hline $1992 b$ & 7.2 & 3.80 & III $>$ II & 6.7 & 3.58 & III $>$ II \\
\hline $1992 \mathrm{C}$ & $1.1 \mathrm{~ns}$ & & & $0.8 \mathrm{~ns}$ & & \\
\hline
\end{tabular}

highest number and the greatest diversity of larvae (Table 3, Fig. 5); however, specific patterns of abundance varied among species. For example, the supply of Stegastes partitus was greater in the south, while the supply of Acanthurus bahianus was often greater in the north. The supply of specific larvae tended to be greater at either end of the island. Only 2 of the more common species, Holocentrus coruscus and Ophioblennius atianticus, were collected in greater abun- dance at the central site (Kruskal-Wallis: $H=6.01$ to 6.06, $\mathrm{p}=0.048, \mathrm{df}=2$ ).

\section{Nearshore current patterns}

Although examination of the nearshore current patterns was hindered by problems with the concurrent functioning of all current meters, several general fea-
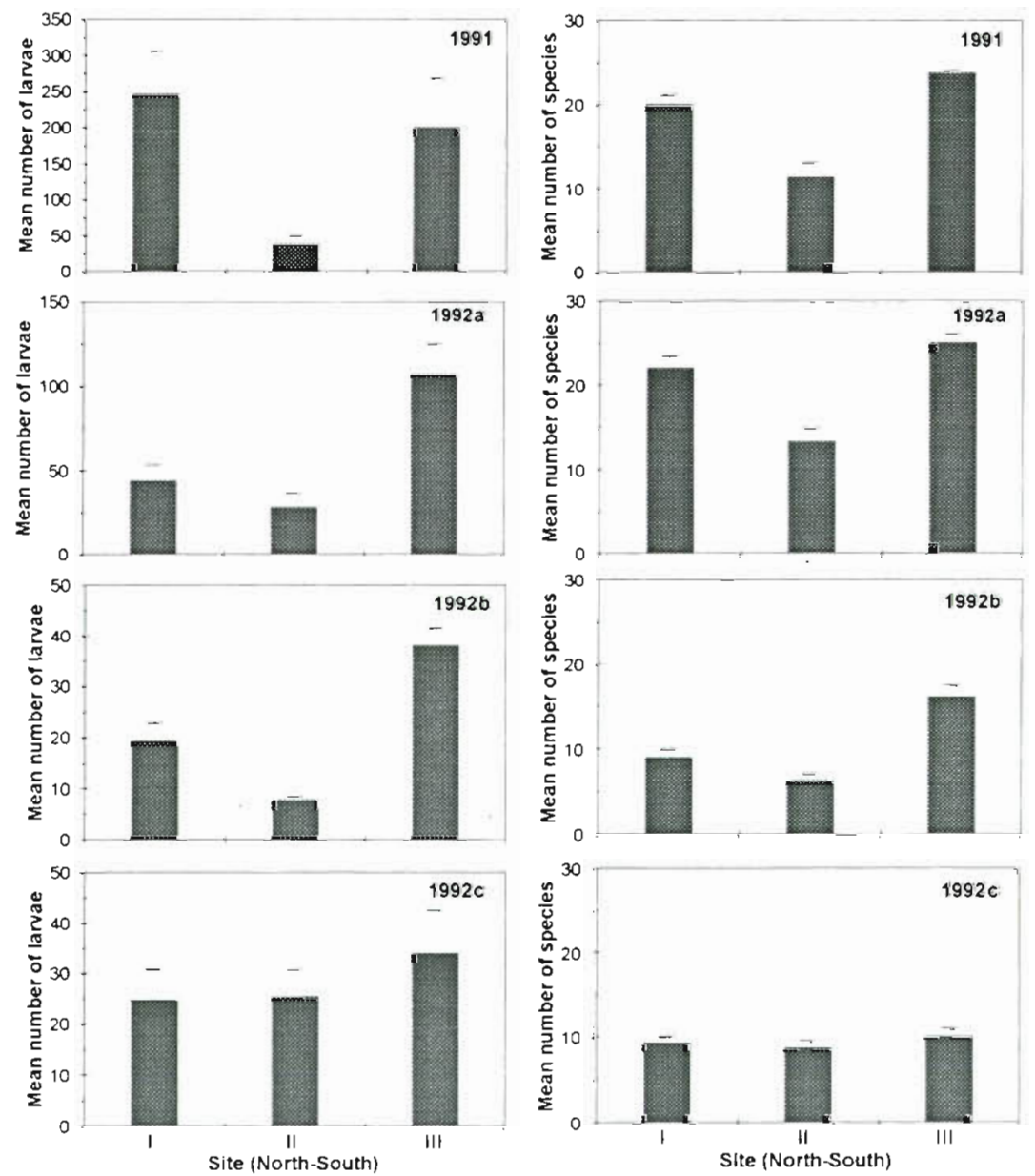

Fig. 5. Spatial pattern of larval supply along the west coast of Barbados. Mean abundance (left, $+1 \mathrm{SE}$ ) and mean diversity (right, $+1 \mathrm{SE}$ ) of larvae collected at each of 3 sites during 4 settlement events (1 in 1991, and 3 in 1992). Note that $y$-axis scales differ among graphs 
Table 4. Cross-correlations between filtered biological data from the light traps and filtered physical current meter data. The total number of fish larvae collected in light traps at each site was smoothed prior to analysis. Transport in the north-south (v) and eastwest (u) directions was integrated over each night for currents with periods of greater than $39 \mathrm{~h}$ (LP, low pass filtered; event related) and less than $39 \mathrm{~h}$ ( $\mathrm{HF}$, high frequency; tidal and other currents). Where transport patterns differed among sites, cross-correlations were performed separately for each site (HF u only). Where transport patterns were similar among sites, cross-correlations were performed between mean nightly transport and the mean number of larvae collected the next day. Due to various malfunctions, only data from the first deployment were used at the central site, and data from the second deployment at the northern site. Data were used from both current meter deployments at the southern site. Where significant cross-correlations existed, lag in days and correlation coefficient (in parentheses) are indicated; bold values are the highest correlation for each test. ns: not significant

\begin{tabular}{|c|c|c|c|c|}
\hline & $\begin{array}{c}\text { HFu } \\
\text { Separate sites }\end{array}$ & $\begin{array}{c}\mathrm{HF} v \\
\text { Mean of all sites }\end{array}$ & $\begin{array}{c}\text { LP u } \\
\text { Separate sites }\end{array}$ & $\begin{array}{c}\text { LP y } \\
\text { Separate sites }\end{array}$ \\
\hline Northern site & ns & ns & $-15(-0.43)$ & $\begin{array}{l}-11(-0.34) \\
-10(-0.41)\end{array}$ \\
\hline Central site & $\begin{array}{l}-7(0.47) \\
-6(0.56) \\
-5(0.49)\end{array}$ & & $\begin{array}{r}-2(0.34) \\
-1(0.40) \\
0(\mathbf{0 . 4 5 )}\end{array}$ & $\begin{array}{r}-9(-0.40) \\
-8(-0.32) \\
-2(-0.30) \\
-1(-0.31) \\
0(-0.32)\end{array}$ \\
\hline Southern site & $\begin{array}{c}-6(0.30) \\
0(-0.34) \\
1(-0.35) \\
2(-0.39) \\
4(-0.33) \\
5(-0.33) \\
6(-0.38) \\
10(0.37) \\
11(0.35)\end{array}$ & & $\begin{array}{l}1(0.42) \\
2(0.39) \\
3(0.34) \\
4(0.34) \\
5(0.32)\end{array}$ & $\begin{array}{l}1(-0.40) \\
2(-0.45) \\
3(-0.41) \\
4(-0.30)\end{array}$ \\
\hline
\end{tabular}

tures of the flow were apparent, including several siterelated differences. Overall, there was general concordance in north-south flow across the 3 sites, although occasionally currents flowed in opposite directions for brief periods of time, which may have resulted in nearshore regions of convergence or divergence along the coast. Most of the transport due to high frequency and low pass filtered currents occurred in the northsouth direction, with relatively less east-west transport (Fig. 6). In general, tidal currents produced maximum nightly transport to the south during maximum amplitude tides associated with the new and full moons, while maximum nightly transport to the north occurred during minimum amplitude tides at the quarter moons (Fig. 6). However, the overall mean abundance of larvae was not significantly related to the mean high frequency north-south transport record (Table 4).

Transport in the east-west direction by tidal currents was noticeably different among sites. Transport by tidal currents was generally onshore (east) at the southern and northern sites, and offshore (west) at the central site. Patterns of transport by tidal currents during the first deployment were almost exactly opposite between the southern and central sites (Fig. 6). During the second deployment, trends in the east-west direction of tidal transport were initially similar and then opposite in shape between the southern and northern sites, although the overall direction of transport remained onshore throughout (Fig. 6). Site-specific tem- poral patterns of larval supply were significantly correlated to east-west transport by tidal currents at the southern and central sites (Table 4).

Nightly transport along both axes due to large-scale, externally forced currents was similar along the coast (Fig, 6). Most of the transport due to low pass filtered currents was directed offshore and towards the north. Overall temporal patterns of larval supply were negatively related to these flows (Table 4). Although the direct relation of larval abundance to north-south low pass transport was less apparent visually, peaks in the number of larvae appeared to be associated with largescale onshore flow (Fig. 6). Due to the shortness of the records, further resolution of the energy underlying this forcing could not be made; however, qualitative comparisons to the wind record suggest that some of the fluctuations in the low pass filtered record may be due to wind events. For example, during the period from Day 117 to Day 135, a shift in the generally northeastern winds to southeastern winds may have produced the strong northward flow along the west coast (Fig, 6)

\section{DISCUSSION}

Light trap collections made in the Great Barrier Reef (Doherty 1987, Milicich 1988, 1994, Choat et al. 1993, Milicich \& Doherty 1994), the Gulf of California (Brogan 1994), and Barbados share several common fea- 
(a)

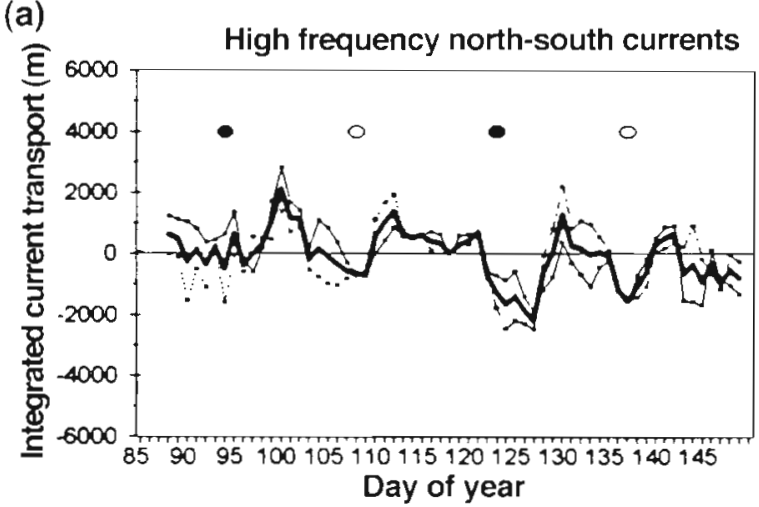

(c)

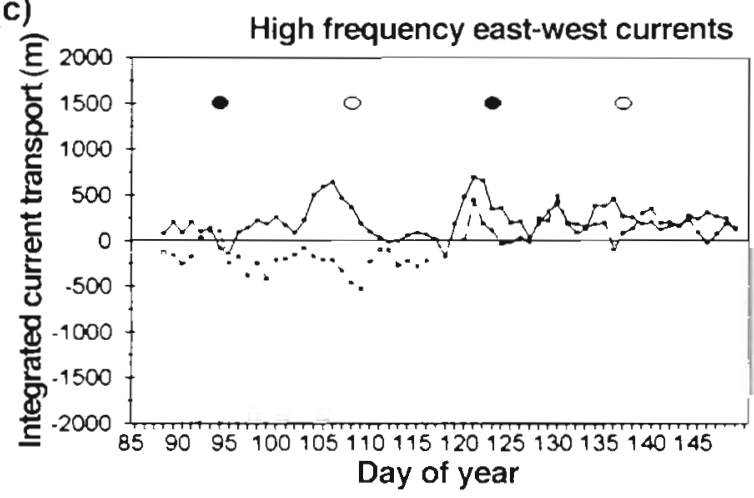

(b)

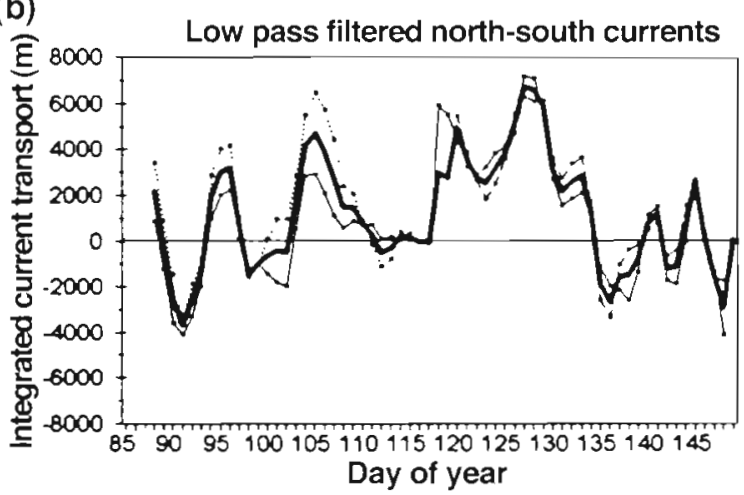

(d)

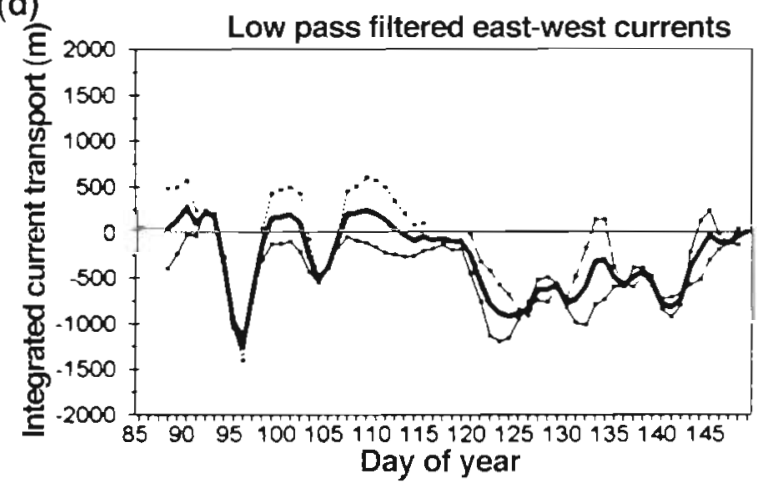

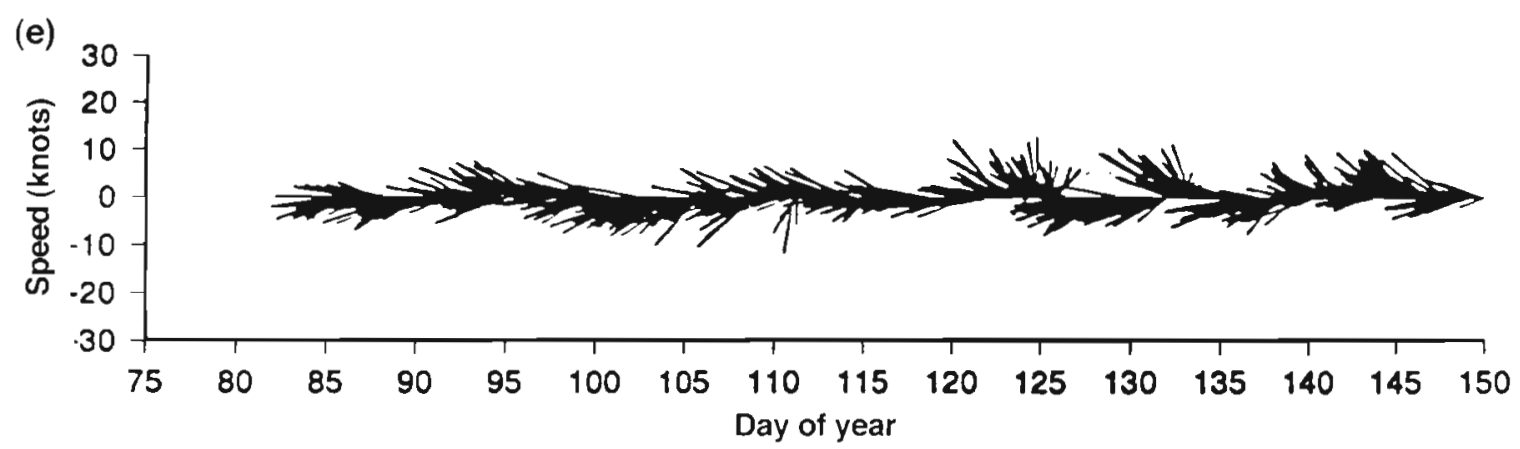

(f)

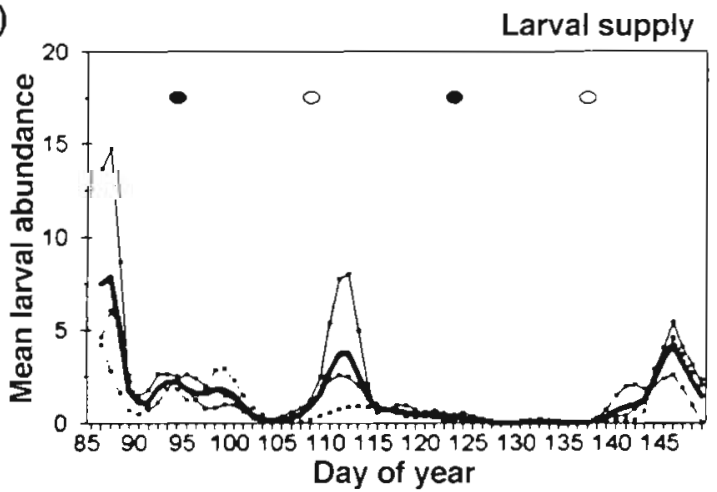

Fig. 6. (a-d) Moving average of nightly transport due to nearshore currents, (e) raw wind record and (f) abundance of all larvae collected in light traps. Transport was calculated from the records of 3 current meters deployed off of the west coast of Barbados. Records were filtered (see text for details) to obtain flows due to tides and other currents (high frequency) and flows due to externally forced events (low pass filtered). Each record was divided into north-south $(t,-)$ and east-west $(t,-)$ components. Where transport records were similar between sites, a mean record was calculated (bold line). Transport: (-) southern site ${ }_{i}(\cdots \cdots \cdots .$.$) central site;$ $(-\ldots)$ northern site. Wind vectors indicate direction of wind travel. (f) Mean larval supply at each site (same lines as above) and mean of all 3 sites (bold line). (O) New moon; (O) full moon 
tures, the most notable being interannual consistency in species composition. Light traps in all 3 geographic locations tended to collect an abundance of pomacentrids and blenniids; however, relatively fewer clupeids and gobiids were collected at Barbados. Oddly, clupeids and gobiids dominated several other night-light (i.e. dip net) collections from Caribbean reefs (Smith et al. 1987, Dennis et al. 1991, Victor 1991). One of the most apparent differences among the collections was the dominance at Barbados of a scarid. The collection of scarids in light traps has rarely been reported from other locations. None has been reported from the Great Barrier Reef (Doherty 1987, Milicich 1988, Choat et al. 1993, Milicich \& Doherty 1994) and one was collected from the Gulf of California (Brogan 1994). Although only 4 scarids were collected (dip nets) from Puerto Rico (Dennis et al. 1991), Victor (1991) collected large numbers in dip nets at Panama. Due to the diverse sampling techniques used at each of these sites, it is unclear whether differences in phototaxis or other larval behaviors occur among these sites. Clearly, preliminary analysis of the species composition collected at a location by particular gear is essential prior to addressing questions of the dynamics of larval supply (e.g. Choat et al. 1993). Late-stage larvae of some species such as pomacentrids appear to be effectively sampled by light traps at a number of geographic locations. Comparisons of the patterns of larval supply of these species can address fundamental questions regarding the physical and biological processes influencing patterns of larval supply (Milicich et al 1992, Meekan et al. 1993, Milicich 1994, this study).

The appearance of many species in the light traps at Barbados was often coupled to the appearance of juveniles on the reef (Sponaugle unpubl. data). The majority of larvae collected by the traps were late-stage larvae; many had attained juvenile coloration by the time traps were retrieved in the morning. Therefore, light traps functioned as a reliable measure of larval supply for a variety of species. Light traps appear to be an especially valuable tool for species that are rather cryptic at settlement (e.g. blenniids and scarids) and thus more difficult to collect as juveniles. For other species, the light traps were obviously inadequate. For example, labrids comprise a significant portion of the ichthyofauna in Barbados, and have been shown to settle to the reef in distinct pulses coupled to the new and third quarter moons (Sponaugle 1994), yet very few labrid larvae were collected in the light traps deployed during the same time periods. In this case, it may not be simply the lack of phototaxis, since some labrid larvae were periodically collected. Although their collection may have been accidental, it is also possible that these larvae exhibit a settlement behavior that is not conducive to collection by surface light traps (e.g. a strong tendency to burrow in the substrate; Victor 1983, Sponaugle pers. obs.) that overwhelms any phototaxis. Alternatively, labrid larvae may move onshore in deeper waters, along the substrate. In this case, relatively more labrids might be collected in shallower, nearshore waters (e.g. Victor 1991).

Perhaps the most striking aspect of the light trap collections at Barbados was the existence of multispecies peaks in larval supply: both the abundance and the diversity of all reef fish larvae collected in the light traps peaked regularly during the third quarter moon. Although a number of common species settle to the reef during new moon periods, settlement during the third quarter moon generally appears to be common in Barbados (Sponaugle \& Cowen 1994, in press). Both pelagic (e.g. acanthurids, several labrids) and demersal spawners (e.g. pomacentrids, blenniids) and species with relatively short and invariant (e.g. pomacentrids) and long and rather flexible larval durations (e.g. several labrids, scarids, acanthurids) follow this pattern (Sponaugle \& Cowen 1994, in press). Settlement by several of these species appears particularly closely synchronized: the temporal record of larval supply was virtually identical for 2 blennies collected in the light traps, as well as for Stegastes partitus and Acanthurus bahianus.

Consistency in patterns of larval supply among taxa has been suggested recently for fishes collected at Lizard Island, Great Barrier Reef (Milicich \& Doherty 1994). Although variability among years was quite high, several taxa exhibited similar temporal patterns of supply (Milicich \& Doherty 1994), and in an earlier study, Milicich (1988) reported that ca $80 \%$ of all larvae collected during her study were collected during a single $6 \mathrm{~d}$ event. While the supply of late-stage larvae of some species may be influenced by larval production (e.g. Robertson et al. 1988, Meekan et al. 1993), interspecific similarities in the timing of larval supply suggest that common environmental cues induce settlement or that larvae are passively entrained in similar transport features

Evidence from the nearshore current meters and a recent comparison of the recruitment patterns of a labrid between 2 geographic locations (Sponaugle 1994) suggest that pulses in larval supply and recruitment to Barbados during the third quarter moon may be related to variation in the tidal amplitude and lunar cycles. In Barbados, the timing of the tidal amplitude cycle is very closely linked to the lunar cycle, and it is difficult to separate the influence of these 2 factors. However, significant correlations between the biological data and the east-west component of transport by tidal currents suggest that tides may influence the nearshore supply of larvae. Although there was no significant relation between north-south tidal transport 
and the abundance of larvae nearshore, pulses in the supply of larvae occurred during periods of maximum nightly northward transport associated with the third quarter moon. Because these peaks in larval abundance were associated with flow during the third quarter moon, but not during the first quarter moon, it is likely that larval supply is influenced not only by the tidal amplitude cycle but by aspects of the lunar phase such as the relative brightness at night. The moon during the third quarter is waning, thus nights are becoming relatively darker and the number of dark hours at night is increasing. The opposite is true during the first quarter moon leading up to the full moon. Thus, larval supply may peak only during the darkest time of northward transport by tidal currents. In a study on a slightly different scale, Shenker et al. (1993) found that movement of fishes through tidal inlets in the Bahamas only occurred during flood tides at the darkest times of the night.

The overall temporal pattern of larval supply aIso was related to transport due to large-scale, externally forced events. Although it was impossible to determine the direct causes of these events, at least several may have been related to strong wind shifts. Episodic shifts in the prevailing northeasterly trade winds to more southeasterly winds may have created large-scale nearshore surface transport to the north along the west coast. These events were usually coupled to increased transport offshore. However, peaks in larval abundance appeared to be roughly associated with periods of large-scale, externally forced onshore transport. It is possible that the particularly low levels of larval supply during the second half of 1992 were related to an extended period of offshore event-related current flow. Similarly, although there are no physical data to support this possibility, the large 1991 pulse in larval supply may have occurred during a period with relatively little event-related offshore transport. Shenker et al. (1993) and Thorrold et al. (1994a) found that the collection of larvae in channel nets in Exuma Sound, Bahamas, during 1 yr peaked during periods when winds and currents exhibited a strong cross-shelf component. In other systems, onshore movements of several temperate fishes also may be associated with wind-driven events (e.g. Checkley et al. 1988, Fenchhelm \& Fissel 1988, Castonguay et al. 1992). In addition to wind shifts, a variety of oceanographic features of remote origin (Bowman et al. 1994, Richardson et al. 1994, Castro 1995) may interupt nearshore currents at Barbados and influence the distribution of larvae (Cowen \& Castro 1994). Such large-scale current shifts can remove larvae from nearshore areas of retention (Boekhoudt 1992, Cowen \& Castro 1994, Castro 1995), reducing the supply of settlement-stage larvae. Other large-scale events have been shown to transport lar- vae of several temperate and tropical reef fishes (Victor 1984, 1986, Cowen 1985, Choat et al. 1988)

The overall spatial pattern of larval supply along the west coast of Barbados was also quite distinct: the lowest abundance and diversity of all species were typically collected at the central site. This spatial pattern was also reflected in the overall pattern of juvenile recruitment during the same periods (Sponaugle unpubl. data). Based on these similar patterns between light traps and recruitment, and no obvious differences in turbidity between sites, the pattern of light trap collection likely reflects the supply of larvae to the island. For many species, including some not sampled well by the light traps (i.e. labrids), the supply of larvae and subsequent recruitment by juveniles was higher at one or the other (or both) ends of the island. The temporal pattern of larval supply was similar among sites: collections of late-stage larvae peaked on the same nights at all 3 sites, and events were of similar duration at each site Thus, the supply of larvae to the west coast generally occurred on the scale of the island, but the magnitude of most events was greater at either end of the island.

Evidence from the current meter records suggests that the spatial pattern of larval supply may be influenced by variation in the east-west transport by tidal currents. In contrast to either end of the west coast, transport due to tidal currents was predominantly offshore in the central region of the island. In addition, during the first deployment, the transport record from the central site was almost exactly a mirror image of that from the southern site, suggesting that the influence of tides differs substantially along the coast. Assuming that larvae are supplied from waters or regions offshore of the reefs, a difference in transport along the east-west axis could have important consequences. Due to this generally offshore component of transport by tidal currents, fewer larvae may be supplied to nearshore waters and reefs in the central region of the coast.

In conclusion, the supply of reef fish larvae to Barbados occurs rather predictably on both a temporal and a spatial scale. Large multispecies pulses of larvae are typically abundant nearshore during the third quarter moon when nightly transport by tidal. currents is directed northward. These peaks in larval abundance and diversity are most likely linked to variation in both the lunar and tidal amplitude cycles. Superimposed on this temporal pattern is the influence of large-scale, externally forced events. Wind or oceanographic event-related changes in the nearshore flow may remove larvae from the system, while pulses in the nearshore supply of larvae may be associated with episodic onshore flow. Spatial patterns in larval supply may be driven by among-site differences in nightly transport by tidal currents. Stronger onshore tidal 
transport at the northern and southern sites may result in a higher supply of larvae to these areas.

Acknowledgements. S. Morgan provided valuable discussions and, with R. Cerrato, D. Conover, K. Lwiza, R. Warner, and 2 anonymous reviewers, substantially improved an earlier draft of the manuscript. Assistance with the construction or deployment of the light traps was provided by B. Boekhoudt, S. Cuppulo, J. Hare, D. Johnson, K. Miles, M. Rodriguez, $\Upsilon$ Rotunno, and T. Wilson. B. Boekhoudt, L. Castro, and J. Hare advised on questionable larval identifications. K. Stansfield and $\mathrm{K}$. Lwiza helped analyze the current meter records, and L. Heilman assisted with the biological filtering. Field facilities were made available through the Bellairs Research Institute of McGill University and $W$. Hunte. This research was supported by National Science Foundation Grant No. OCE-8911120 to R.K.C and M J. Bowman. This represents contribution no. 1021 from the Marine Sciences Research Center

\section{LITERATURE CITED}

Batschelet E (1981) Circular statistics in biology. Academic Press, New York

Boekhoudt B (1992) The effect of current shifts on larval fish distributions around Barbados. MS thesis, State University of New York, Stony Brook

Bowman MJ, Stansfield KL, Fauria SJ, Wilson TC (1994) Coastal ocean circulation near Barbados, West Indies Spring 1990 and 1991. J Geophys Res 99:16131-16142

Brogan MW (1994) Two methods of sampling fish larvae over reefs: a comparison from the Gulf of California. Mar Biol 118:33-44

Castonguay R, Rose GA, Leggett WC (1992) Onshore movements of Atlantic mackerel (Scomber scombrus) in the northern Gulf of St. Lawrence: associations with windforced advections of warmed surface waters. Can J Fish Aquat Sci 49:2232-2241

Castro LR (1995) Ichthyoplankton distribution around Barbados: patterns and processes conducive to retention. $\mathrm{PhD}$ dissertation, State University of New York, Stony Brook

Checkley DM Jr, Raman S, Maillet GL, Mason KM (1988) Winter storms effects on the spawning and larval drift of a pelagic fish. Nature 335:346-347

Choat JH, Ayling AM, Schiel DR (1988) Temporal and spatial variation in an island fish fauna.J Exp Mar Biol Ecol 121 $91-111$

Choat JH, Doherty PJ, Kerrigan BA, Leis JM (1993) A comparison of towed nets, purse seine, and light-aggregation devices for sampling larvae and pelagic juveniles of coral reef fishes. Fish Bull US 91:195-209

Cowen RK (1985) Large scale pattern of recruitment by the labrid, Semicossyphus pulcher: causes and implications J Mar Res 43:719-742

Cowen RK, Castro LR (1994) Relation of coral reef fish larval distributions to island scale circulation around Barbados, West Indies. Bull Mar Sci 54:228-244

Dennis GD, Goulet D, Rooker JR (1991) Ichthyoplankton assemblages sampled by night-lighting in nearshore habitats of southwestern Puerto Rico. NOAA Natn Mar Fish Serv Tech Rep US Dept Commerce 95:89-97

Doherty PJ (1981) Coral reef fishes: recruitment limited assemblages? Proc 4th Int Coral Reef Symp 2:465-470

Doherty PJ (1987) Light traps: selective but useful devices for quantifying the distributions and abundances of larval fishes. Bull Mar Sci 41:423-4.31
Doherty PJ (1991) Spatial and temporal patterns in recruitment. In: Sale PF (ed) The ecology of fishes on coral reefs Academic Press, San Diego, p 261-293

Doherty P, Fowler A (1994a) An empirical test of recruitment limitation in a coral reef fish. Science 263:935-939

Doherty P, Fowler A (1994b) Demographic consequences of variable recruitment to coral reef fish populations: a congeneric comparison of two damselfishes. Bull Mar Sci 54:297-313

Doodson AT, Warburg HD (1941) Admiralty manual of tides. Her Majesty's Stationery Office, London

Dufour V, Galzin R (1993) Colonization patterns of reef fish larvae to the lagoon at Moorea Island, French Polynesia. Mar Ecol Prog Ser 102:143-152

Fenchhelm RG, Fissel DB (1988) Wind-aided recruitment of Canadian Arctic cisco (Coregonus autumnalis) into Alaskan waters. Can J Fish Aquat Sci 45:906-910

Forrester GE (1990) Factors influencing the juvenile demography of a coral reef fish population. Ecology 71 $1666-1681$

Gaines SD, Bertness MD (1992) Dispersal of juveniles and variable recruitment in sessile marine species. Nature 360 : $579-580$

Gaines S, Brown S, Roughgarden J (1985) Spatial variation in larval concentrations as a cause of spatial variation in settlement for the barnacle, Balanus gladula. Oecologia 67 $267-272$

Hixon MA (1991) Predation as a process structuring coral-reef fish communities. In: Sale PF (ed) The ecology of fishes on coral reefs. Academic Press, San Diego, p 475-508

Hixon MA, Beets JP (1993) Predation, prey refuges, and the structure of coral-reef fish assemblages. Ecol Monogr 63: $77-101$

Hunt von Herbing I, Hunte W (1991) Spawning and recruitment of the bluehead wrasse Thalassoma bifasciatum in Barbados, West Indies. Mar Ecol Prog Ser 72:49-58

Jones GP (1990) The importance of recruitment to the dynamics of a coral reef fish population. Ecology 71 $1691-1698$

Jones GP (1991) Postrecruitment processes in the ecology of coral reef fish populations: a multifactorial perspective. In: Sale PF (ed) The ecology of fishes on coral reefs. Academic Press, San Diego, p 294-328

Keough MJ (1988) Benthic populations: is recruitment limiting or just fashionable? Proc 6th Int Coral Reef Symp 1: $141-148$

Kingsford MJ, Choat JH (1985) The fauna associated with drift algae captured with a plankton-mesh purse seine net. Limnol Oceanogr 30:618-630

Krauss TP, Shure L, Little JN (1988) Signal processing toolbox for use with MATLAB. The Mathworks, Inc, Natick

Leis JM (1991) The pelagic stage of reef fishes: the larval biology of coral reef fishes. In: Sale PF (ed). The ecology of fishes on coral reefs. Academic Press, San Diego, p $183-230$

Luckhurst BE, Luckhurst K (1977) Recruitment patterns of coral reef fishes on the fringing reefs of Curacao, Netherlands Antilles. Can J Zool 55:681-689

McFarland WN, Brothers EB, Ogden JC, Shulman MJ, Bermingham EL, Kotchian-Prentiss NM (1985) Recruitment patterns in young French grunts, Haemulon flavolineatum (Family Haemulidae), at St. Croix, Virgin Islands. Fish Bull US 83:413-426

Meekan MG, Milicich MJ, Doherty PJ (1993) Larval production drives temporal patterns of larval supply and recruitment of a coral reef damselfish. Mar Ecol Prog Ser 93: $217-225$ 
Middaugh DP, Domey RG, Scott GI (1984) Reproductive rhythmicity of the Atlantic silverside. Trans Am Fish Soc $113: 472-478$

Milicich MJ (1988) The distribution and abundance of presettlement fish in the nearshore waters of Lizard Island. Proc 6th Int Coral Reef Symp 2:785-790

Milicich MJ (1994) Dynamic coupling of reef fish repienishment and oceanographic processes. Mar Ecol Prog Ser $110: 135-144$

Milicich MJ, Doherty PJ (1994) Larval supply of coral reef fish populations: magnitude and synchrony of replenishment to Lizard Island, Great Barrier Reef Mar Ecol Prog Ser 110:121-134

Milicich MJ, Meekan MG, Doherty PJ (1992) Larval supply: a good predictor of recruitment of species of reef fish (Pomacentridae). Mar Ecol Prog Ser 86:153-166

Munro JL, Gaunt VC, Thompson R, Reeson PH (1973) The spawning seasons of Caribbean reef fishes. J Fish Biol 5: $69-84$

Oppenheim AV, Schafer RW (1975) Digital signal processing. Prentice-Hall, Princeton

Peterson CH, Summerson HC (1992) Basin-scale coherence of population dynamics of an exploited marine invertebrate. the bay scallop: implications of recruitment limitation. Mar Ecol Prog Ser 90:257-272.

Powles H (1975) Abundance, seasonality, distribution and aspects of the ecology of some larval fishes off Barbados PhD dissertation, McGill University, Montreal

Richardson PL, Hufford. G, Limeburner R, Brown WS (1994) North Brazil Current retroflection eddies. J Geophys Res 99:5081-5093

Robertson DR, Green DG, Victor BC (1988) Temporal coupling of production and recruitment of a larvae of a Caribbean reef fish. Ecology 69:370-381

Roughgarden J, Gaines S, Possingham H (1988) Recruitment dynamics in complex life cycles. Science 241:1460-1466

Shenker JM, Maddox ED, Wishinski E, Pearl A, Thorrold S, Smith $N$ (1993) Onshore transport of settlement-stage Nassau grouper Epinephelus striatus and other fishes in Exuma Sound, Bahamas. Mar Ecol Prog Ser 98:31-43

Smith CL, Tyler JC, Stillman L (1987) Inshore ichthyoplankton: a distinctive assemblage? Bull Mar Sci 41:432-440

Sponaugle S (1994) Recruitment processes of Caribbean reef fishes. PhD dissertation. State University of New York, Stony Brook

Sponaugle S, Cowen RK (1994) Larval durations and recruitment patterns of two Caribbean gobies (Gobiidae): contrasting early life histories in demersal spawners. Mar Biol 120:133-143

This article was presented by C. H. Peterson (Senior Editorial Advisor), Morehead (ity, North Carolina, USA
Sponaugle S, Cowen RK (in press) Larval supply and patterns of recruitment for two Caribbean reef fishes, Stegastes partitus and Acanthurus bahianus. J Mar Freshwat Res

Thorrold SR (1992) Evaluating the performance of light traps for sampling small fish and squid in open waters of the central Great Barrier Reef lagoon. Mar Ecol Prog Ser 89; $277-285$

Thorrold SR (1993) Post-larval and juvenile scombroids captured in light traps: preliminary results from the central Great Barner Reef lagoon. Bull Mar Sci 52:631-641

Thorrold SR, Milicich M (1990) Comparison of larval duration and pre-and post-settlement growth in two species of damselfish, Chromis atripectoralis and Pomacentrus coelestis (Pisces: Pomacentridae), from the Great Barrier Reef. Mar Biol 105:375-384

Thorrold SR, Shenker JM, Maddox ED, Mojica R Jr, Wishinski $E$ (1994a) Larval supply of shorefishes to nursery habitats around Lee Stocking Island, Bahamas. II. Lunar and oceanographic influences. Mar Biol 118:567-578

Thorrold SR, Shenker JM, Mojica R Jr, Maddox ED, Wishinski E (1994b) Temporal patterns in the larval supply of summer-recruiting reef fishes to Lee Stocking Island, Bahamas. Mar Ecol Prog Ser 112:75-86

Thorrold SR, Shenker JM, Wishinski E, Mojica R Jr, Maddox ED (1994C) Larval supply of shorefishes to nursery habitats around Lee Stocking Island, Bahamas. I. Small-scale distribution patterns. Mar Biol 18:555-566

Tupper M. Hunte W (1994) Recruitment dynamics of coral reef fishes in Barbados. Mar Ecol Prog Ser 108:225-235

Victor BC (1983) Settlement and larval metamorphosis produce distinct marks on the otoliths of the slippery dick, Halichoeres bivittatus. In: Reaka ML (ed) The ecology of deep and shallow coral reefs. NOAA Symp Ser Undersea Res 1:47-51

Victor BC (1984) Coral reef fish larvae: patch size estimation and mixing in the plankton. Limnol Oceanogr 29 $1116-1119$

Victor BC (1986) Larval settlement and juvenile mortality in a recruitment-límited coral reef fish population. Ecol Monogr 56:145-160

Victor BC (1991) Settlement strategies and biogeography of reef fishes. In: Sale PF (ed) The ecology of fishes on coral reefs. Academic Press, San Diego, p 231-260

Warner RR, Hughes TP (1988) The population dynamics of reef fishes. Proc 6th Int Coral Reef Symp 1:149-155

Wilkinson L (1987) SYSTAT: the system for statistics. SYSTAT, Inc, Evanston, IL

Zar JH (1984) Biostatistical analysis. Prentice-Hall, Englewood Cliffs

Manuscript first received: February 8, 1995

Revised version accepted: August 24, 1995 